УДК 329.055

https://doi.org/10.34142/24130060.2019.17.1.11

\title{
ТРАДИЦІЇ РОЗРІЗНЕННЯ ПРАВИХ ТА ЛІВИХ ПОЛІТИЧНИХ ПАРТІЙ: МЕТОДОЛОГІЧНИЙ КОНТЕКСТ
}

\author{
Г.М. Куц \\ Харківський національний педагогічний університет імені Г.С. Сковороди
}

Розглянуто традицію право/лівого розрізнення політичних сил у методологічному контексті. Здійснено аналіз базових принципів, які є визначальними у віднесенні певних політичних партій до правого чи лівого політичного спектру.

Розмежування на «лівих» $i$ «правих» в українському суспільстві доволі слабке. Значна частина респондентів в Україні не мають уявлення про відмінності між правими чи лівими партіями, щз свідчить про низький рівень політичної інформованості. Партійні протистояння в Україні під час електоральних кампаній найчастіше перетворюються на протистояння ціннісних - але не ідеологічних - пріоритетів.

Ключові слова: «праві», «ліві», політичні партії, політичні ідеології, ичінності, українське суспільство, методологічний контекст.

\section{ТРАДИЦИИ РАЗЛИЧЕНИЯ ПРАВЫХ И ЛЕВЫХ ПОЛИТИЧЕСКИХ ПАРТИЙ: МЕТОДОЛОГИЧЕСКИЙ КОНТЕКСТ}

\section{Г.М. Куц}

Рассмотрена традищия право/левого различения политических сил в методологическом контексте. Осуществлен анализ базовых принщипов, являющихся определяющими в отнесении определенных политических партий к правому или левому политическому спектру.

Разграничение на «левых» и «правых»в украинском обществе довольно слабое. Значительная часть респондентов в Украине не имеют представления о различиях между правыми или левыми партиями, что свидетельствует о низком уровне политической информированности. Партийные противостояния в Украине во время электоральных кампаний зачастую превращаются в противостояние иенностных - но не идеологических - приоритетов.

Ключевые слова: «правые», «левые», политические партии, политические идеологии, ценности, украинское общество, методологический контекст.

\section{TRADITIONAL DISCLOSURES OF RIGHT AND LEFT POLITICAL PARTIES: METHODOLOGICAL CONTEXT}

\section{H. Kuts}

The tradition of right/left separation of political forces in the methodological context is considered. The analysis of the basic principles that are crucial in assigning certain political parties to the right or left political spectrum is carried out. In particular, in the field of economics, the «right» is to identify those political forces that uphold the principles of private property, its priorities for collective ownership. «Left» political forces, on the contrary, support 
the idea of collectivization, nationalization, socialization, and so on. For the «right» political forces, priority is given to the principles of individualism, whereas for the «left»-collectivism.

The distinction between «left» and «right» in Ukrainian society is rather weak. A large proportion of respondents in Ukraine do not have an idea of the differences between the rightwing parties or the left-wing parties, which indicates, first of all, the low level of their political awareness. Accordingly, when voting in parliamentary (or local) elections, Ukrainian voters choose a certain party not for its ideological features, but for other criteria. Often, Ukrainian voters are guided by a personalistic criterion, focusing on those who head the political party. Also important role - in the absence of understanding ideological priorities - acquires a value criterion (mainly at the level of the archetype «own»/«alien»).

It was stated that party confrontations in Ukraine during electoral campaigns often turn into conflicts of values - but not ideological - priorities. That is, the attraction to values and principles, and not to ideological doctrines, is the main feature of most political parties of modern Ukraine.

Key words: «right», «left», political parties, political ideologies, values, Ukrainian society, methodological context.

\section{Постановка проблеми. Сучасні тенденції трансформації світу} політичного, будучи пов'язаними з кризою традиційних та появою нових політичних інститутів, характеризуються глибокими змінами у характері політичних відносин на різних рівнях (локальний, національний, глобальний). Це ставить вимогу стосовно якісного оновлення теоретикометодологічного інструментарію пізнання об’єктів політичного світу. Саме тому звернення до аналізу традиції розрізнення правих та лівих сил політичного спектру у методологічному контексті $\epsilon$ виправданим i надзвичайно актуальним.

Аналіз актуальних досліджень. Вважається, що традиція розрізнення політичних сил на «правих» та «лівих» бере свій початок ще із часів Великої Французької революції 1789 р. 3 того часу у більшості наукових досліджень політичного дискурсу проблематика право/лівого спектру політичних сил переважно корелювала 3 проблематикою політичних ідеологій та проблематикою політичних партій, що відобразилося у працях багатьох теоретиків (Р. Арон, Е. Берк, П. Дж. Б’юкенен, І. Валлерстайн, Й. Жіма, К. Манхейм, Л. фон Мізес, М. Дюверже, Ф. А. фон Хайєк, Р. Шуттінгер, Д. Юм та ін.).

Метою статті стало виявлення специфіки традиції розрізнення правих та лівих політичних партій у методологічному контексті. Завдання статті 
полягає у виокремленні базових принципів, які є визначальними у віднесенні певних політичних партій до правого чи лівого політичного спектру. Також завданням статті став розгляд ситуації щодо розмежування на «лівих» i «правих» в українському політичному полі.

Виклад основного матеріалу. Прийнято вважати, що традиція розрізнення політичних сил - «правих» та «лівих» - бере свій початок із часів Великої Французької революції 1789 р., коли на засіданні французького парламенту з правого боку від голови сідали консерватори, метою яких було збереження монархії, зліва - радикали, які підтримували ідею загальної рівності, а помірковані займали місця по центру зали. 3 того часу адептів збереження існуючого ладу стали означувати «правими», а прихильників радикальних змін - «лівими» (Куц, 2011, с. 85).

У сфері економіки «правими» прийнято означувати ті політичні сили, які відстоюють принципи приватної власності, iï пріоритети перед колективною власністю. «Ліві» сили, натомість, підтримують ідеї колективізації, націоналізації, усуспільнення тощо. На думку Р. Арона, дотримуватися лівих поглядів «означає йти за допомогою націоналізації та контролю до рівності прибутків» (2006, с. 24). «Ліві» ідеології найчастіше надихаються «трьома ідеями, не конче суперечливими, а найчастіше різнобічними: свобода проти свавілля влади й за безпеку осіб, організація 3 метою, щоб замінити мимовільний порядок традиції чи анархії індивідуальних ініціатив якимсь раціональним порядком, рівність проти привілеїв за народженням і за багатством» $(2006$, с. 40).

Вважається, що для «правих» пріоритетними $є$ принципи індивідуалізму, тоді як для «лівих» - колективізму. Така точка зору детермінована тим, що 3 правим спектром традиційно співвідносять лібералізм, для якого базовими є індивідуалістичні цінності. Втім, інколи лібералів відносять до «центристів», інколи навіть до «лівих». Так, П. Дж. Б’юкенен (2006, с. 253), протиставляючи лібералів консерваторам, відносить їх до «лівого» спектру. 
У вельми спрощеному вигляді «спектр політичних течій може бути представлений таким чином: крайні «ліві» (комуністи) - соціалісти - соціалдемократи - ліберали - консерватори (народники, націоналісти) - крайні «праві»» (Здорик, 2009, с. 199). Подібну інтерпретацію право/лівої шкали політичного спектру (див. рис. 1.) подає Й. Жіма (2002, s. 11).

\begin{tabular}{|lrr|}
\hline Комуністи & Соціал-демократи & Ліберали \\
Лівцй спектр & Фаписти (нацисти) \\
Правий спектр
\end{tabular}

Рис. 1. Право/ліва шкала політичного спектру у контексті типології Й. Жіми (2002, s. 11)

Схожі погляди можна виявити у Р. Арона, який вважав, що більшовизм i франкізм - це дві крайності, які знаходяться на протилежних полюсах право/лівої шкали політичного спектру. Причому, «перший спирається на ліву ідеологію, раціоналізм, поступ, свободу, другий - на контрреволюційну ідеологію, родину, релігію, владу» (2006, с. 26-27). Разом 3 тим, на думку Р. Арона, праві та ліві можуть навіть поєднуватися за умов тоталітаризму. «Доречно зауважити, що гітлерівський тоталітаризм є правим, а сталінський - лівим під тим приводом, що один запозичує ідеї в контрреволюційного романтизму, інший же - в революційного раціоналізму, так само, як один має себе за особливого, національного чи расового, інший же - за всезагальний завдяки класові, обраному історією» (2006, с. 27).

Отже, найчастіше класичні політичні ідеології представляють «у вигляді різних, розташованих в ряд позицій, з-посеред яких соціалісти знаходяться зліва, консерватори справа, а ліберали десь посередині» (Гаєк, 1998, с. 67). Втім, на думку Ф. А. фон Гайєка, таке уявлення є оманливим; 
більш оптимальним видається зведення цих позицій до трикутника, в якому кожна з ідеологічних доктрин займала б відведений для себе кут (1998, с. 67). Метафора «ідеологічного трикутника», на наш погляд, більш вдало відображає непрості взаємовідносини між ідеологічними доктринами, особливо з огляду на відсутність чіткої концептуальної демаркації між ними. Історичні перипетії продемонстрували, що рівностороннім «ідеологічний трикутник» ніколи не був.

Цікавими у цьому контексті видаються уявлення українських громадян про право/ліву шкалу політичного партійного спектру (див. рис 1.). Опитування проводилося у червні 2018 р.

\section{Говорять, що в політиці є "ліві" і "праві". Бүдь ласка, використовуючи шкалу від 1 до 10, де "1" означає "ліві", а "10" - "праві", де за своїми поглядами Ви розташовуєтеся на цій шкалі?}

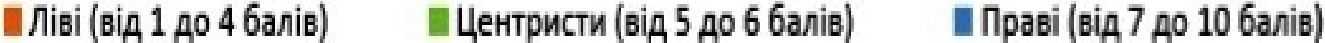

Рис. 2. Формальне розмежування на «лівих» і «правих» в українському суспільстві (Центр Разумкова, 2018,)

Отже, розмежування на «лівих» і «правих» в українському суспільстві доволі слабке. Переважна більшість респондентів (58\%) дотримується центристської позиції. Слід зазначити, що крайні «права» та «ліва» позиції мають однаково низьку популярність в українському суспільстві - близько $2 \%$.

Разом $з$ тим, така ситуація може свідчити ще й про слабку обізнаність населення України стосовно ідеологічних відмінностей між «правими» та «лівими» політичними силами. I, дійсно, коли респондентам задали уточнююче питання щодо самоідентифікації 3 конкретним ідейно- 
політичним напрямом, значна частина опитуваних $(24,0 \%)$ заявили, що взагалі не орієнтуються в політичних течіях (рис. 3).

\section{Скажіть, будь ласка, який ідейно-політичний напрям найбільше відповідає Вашим переконанням? (одна відповідь)}

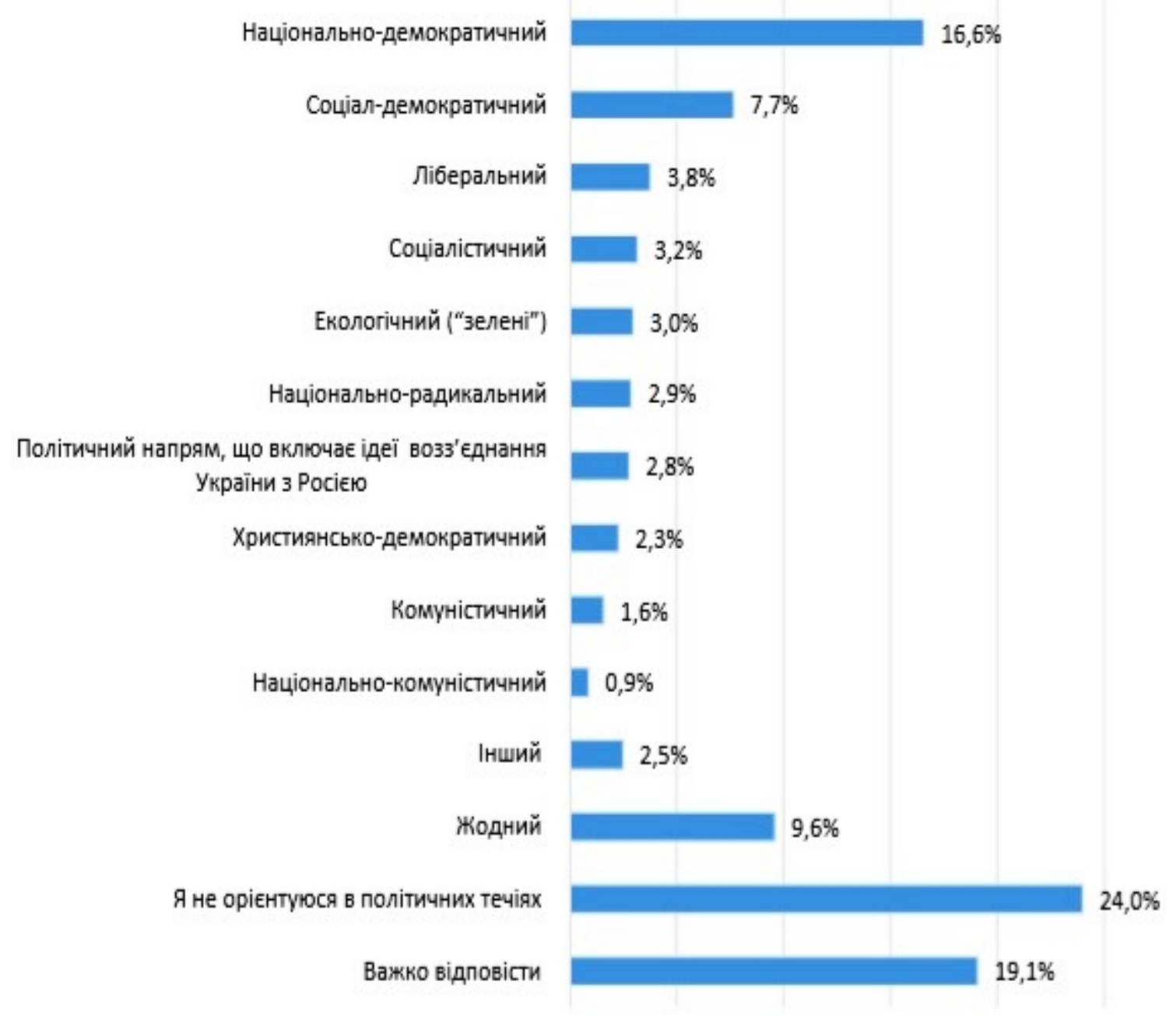

Рис. 3. Розподіл відповідей респондентів в Україні щодо самоідентифікації 3 тим чи іншим ідейно-політичним напрямом (Центр Разумкова, 2018)

Більше того, «в усіх регіонах близько половини опитаних (49\% - на Заході, 55\% - у Центрі, 54\% - на Півдні та 51\% - на Сході) не змогли визначитись щодо самоідентифікації з тим чи іншим ідейно-політичним напрямом» (Центр Разумкова, 2018).

Тобто, значна частина респондентів в Україні взагалі не мають уявлення про відмінності між правими чи лівими партіями, що насамперед 
свідчить про низький рівень їхньої політичної інформованості. Відповідно, при голосуванні на парламентських (чи місцевих) виборах українські виборці обирають певну партію не за іiі ідеологічними ознаками, а за іншими критеріями. Найчастіше українські виборці керуються персоналістичним критерієм, орієнтуючись на осіб, що очолюють партію. Також вагому роль за відсутності розуміння ідеологічних пріоритетів - набуває ціннісний критерій (переважно на рівні архетипу «свій»/«чужий»). Отже, зупинимось на самій проблемі ціннісного протистояння, іiї причинах та витоках.

Партійна палітра сучасної України на перший погляд вельми різноманітна. Але це враження швидко зникає при детальнішому ознайомленні 3 основними положеннями партій. Значна кількість партій майже не демонструє відмінностей в ідеологічних позиціях. Складається враження, що більшість українських партій ідеологіями лише прикривається, активно їх декларуючи у виборчий сезон. У виборчому міжсезонні продовжується мляво-паралельне співіснування одних з іншими.

Кожна з класичних ідеологічних доктрин (лібералізм, соціалізм, консерватизм) передбачає вибір свого - альтернативного іншим доктринам шляху розвитку. Це, насамперед, вибір певних економічних правил існування, політичного ладу тощо. В українському політико-партійному полі, на жаль, ідеологія не виступає тим чинником, який здатний об'єднати адептів певної політичної сили. Необхідно відмітити, що формально українські партії позиціонують себе 3 точки зору класичного розуміння ідеологічної приналежності. Втім, більш активно вони позиціонують себе в якості прихильників (а ще більше захисників) певних цінностей, які інколи не співпадають із задекларованими ідеологічними постулатами. Тяжіння до цінностей та принципів, а не до ідеологічних доктрин - основна риса більшості політичних партій сучасної України.

Чому пріоритет надається ціннісним орієнтаціям та принципам, а не ідеологічним переконанням? Для відповіді на це питання необхідно виявити найбільш суттєві відмінності між ціннісними орієнтаціями та ідеологічними 
переконаннями. Звернемось до Г. Ріккерта (1911), який вважав, що особливою сферою, де одиничні явища співвіднесені 3 цінностями $\epsilon$ культура. Виділяючи два класи наук - «науки про природу» та «науки про культуру», він відмічав, що унікальністю явища у фізичному світі можна нехтувати, тоді як у світі культури всяке одиничне явище є унікальним, його не можна замінити іншим подібним явищем. Скажімо, вивчаючи траєкторію падіння тіла, не має значення яке тіло падає: камінь, м’яч чи щось інше. Тобто, в «науках про природу» пізнати об'єкт - значить підвести його під загальний закон. Це генералізуючий, узагальнюючий метод. Для гуманітарних наук виступає головним індивідуалізуючий метод утворення понять, оскільки дослідника цікавить в предметі одиничне, індивідуальне. В «науках про культуру» як i в природничих науках дійсність також розпадається на суттєве та несуттєве. Але принцип відбору суттєвого інший, ніж в природничих науках. Для природничих наук - це виявлення загального, для культури - це віднесення до цінностей. Цінності мають надіндивідуальний характер, вони загально значимі. Г. Ріккерт вважав, що культура заснована на сукупності цінностей, а не раціональності.

Отже, цінності детерміновані культурою і не співвідносяться 3 раціональністю. Повернемось до ідеологій, у кожній 3 яких поряд 3 елементом ірраціональності, присутній достатньо вагомий елемент раціональної обгрунтованості. Таким чином, відмінності між ідеологічними переконаннями та ціннісними орієнтаціями полягають в наявності чи відсутності раціональних процедур їх обгрунтування. Цінності, найчастіше, сприймаються на віру, тоді як кожна 3 ідеологічних доктрин має свій потужний арсенал засобів раціональної аргументації. Звідси напрошується ще один висновок. Апелювати до цінностей політичним партіям і простіше, i легше. Ціннісні принципи можна задекларувати i забути, позаяк це апелювання ні до чого не зобов'язує. Дотримуватись заявлених ідеологічних догм важче. Адже виборець, голосуючи за ідеологічну доктрину, голосує за певний напрям економічного та політичного розвитку, що зобов'язує 
політичну силу бути передбачуваною і послідовною. Голосуючи за цінності чи принципи, виборці голосують серцем на рівні архетипу «свій-чужий», не маючи уявлення який вектор розвитку обере в подальшому політична сила.

В окресленому контексті доволі важко назвати партіями організаційні об’єднання, які створені лише під вибори. С, звичайно, надія, що в Україні прийде усвідомлення необхідності існування партій у сучасному розумінні цього поняття як інструментів реалізації політичного процесу з наявністю чітко вираженої ідеології та іншими необхідними ознаками таких інститутів. Слід також констатувати, що сьогодні партії в Україні - це, найчастіше, партії лідерів, а не ідеологій.

Враховуючи той факт, що партійна система в Україні ще на стадії свого формування, видається доцільним використання для подальшого аналізу типології партій Д. Юма, в якій ще не вважається, що партія обов'язково має бути носієм певної ідеології. Більше того, оскільки однозначного визначення партії в сучасній політології не існує, багато із запропонованих у різний час визначень беруть свій початок саме від цієї типології, запропонованої у XVIII ст. Д. Юм (1966, с. 601-603) розрізняв три типи партій: партії інтересу, партії принципів і партії прив’язаності (мається на увазі прив’язаність до певних осіб). В Україні легко виявити кожен із заявлених типів, хоча доволі часто вони химерно переплітаються.

Партії в Україні - це, найчастіше, партії прив’язаності. Рекордна кількість іменних передвиборчих блоків на різних виборах - яскраве цьому підтвердження. Причина полягає, ймовірно, в тому, що патерналізм із пострадянської свідомості викорінити важко. Саме в патерналізмі слід шукати корені прагнення до прив’язаності.

Партії, що створені на основі принципу, «особливо принципу абстрактного і умоглядного» (Юм, 1966, с. 601) є незвичним явищем, яке важко пояснити, вважав Д. Юм. Партії принципу чистого типу виявити важко. Вони в Україні найчастіше перебувають в симбіозі 3 партіями прив'язаності. 
Якщо в проблемі ціннісного протистояння просунутись вглиб, то перед нами постануть давні розбіжності між латинськими та візантійськими цінностями. Класичні латинські цінності - це міцна сім'я, релігійні норми і наполегливість (Закария, 2004, с. 47). Візантійські цінності пов'язані 3 патерналізмом та кулуарним вирішенням проблем. Тобто, латинські цінності означають опору людини на свої власні сили у вирішеннях різноманітних проблем. Натомість людина візантійських цінностей вважає, що держава має нею опікуватись та покладає всі надії на вищу мудрість правителя.

Висновки і перспективи подальших досліджень. Здійснено розгляд традиції право/лівого розрізнення політичних сил у методологічному контексті. Здійснено аналіз базових принципів, які $є$ визначальними у віднесенні певних політичних партій до правого чи лівого політичного спектру. Зокрема, у сфері економіки «правими» прийнято означувати ті політичні сили, які відстоюють принципи приватної власності, iї пріоритети перед колективною власністю. «Ліві» політичні сили, натомість, підтримують ідеї колективізації, націоналізації, усуспільнення тощо. Для «правих» політичних сил переважно пріоритетними $є$ принципи індивідуалізму, тоді як для «лівих» - колективізму.

Розмежування на «лівих» і «правих» в українському суспільстві доволі слабке. Значна частина респондентів в Україні взагалі не мають уявлення про відмінності між правими чи лівими партіями, що насамперед свідчить про низький рівень їхньої політичної інформованості. Відповідно, при голосуванні на парламентських (чи місцевих) виборах українські виборці обирають певну партію не за іiі ідеологічними ознаками, а за іншими критеріями. Найчастіше українські виборці керуються персоналістичним критерієм, орієнтуючись на осіб, що очолюють політичну партію. Також вагому роль - за відсутності розуміння ідеологічних пріоритетів - набуває ціннісний критерій (переважно на рівні архетипу «свій»/«чужий»).

Констатовано, що партійні протистояння в Україні під час електоральних кампаній найчастіше перетворюються на протистояння 
ціннісних - але не ідеологічних - пріоритетів. Тобто, тяжіння до цінностей та принципів, а не до ідеологічних доктрин - основна риса більшості політичних партій сучасної України.

\section{ЛIТЕРАТУРА}

1. Арон, Р. 2006. Опій інтелектуалів. Київ: Юніверс.

2. Бьюкенен, П.Дж. 2006. Правые и не-правые. Как неоконсерваторы заставили нас забыть о рейгановской революции и повлияли не президента Буша. Москва: Транзиткнига.

3. Гаєк, Ф.А. фон. 1998. Чому я не консерватор. Київ: Смолоскип.

4. Закария, Ф. 2004. Будущее свободы: нелиберальная демократия в США и за их пределами. Москва: Ладомир.

5. Здорик, М.В., 2009. Концептуалізація термінів «праві»/«ліві» у політико-партійному дискурсі. Вісник ХНУ імені В.Н. Каразіна. Серія «Питання політології», 861(15), с. 196-201.

6. Центр Разумкова, 2018. Ідеологічні орієнтаиії громадян України. [online] Доступно: http://razumkov.org.ua/napriamky/sotsiologichni-doslidzhennia/presreliz-tsentrurazumkova-ideolohichni-oriientatsii-hromadian-ukrainy [Дата звернення 12 грудень 2018].

7. Куц, Г.М. 2011. Ліберальні трансформачії політичного простору. Харків: Віровець А.П.; «Апостроф».

8. Риккерт, Г. 1911. Науки о природе и науки о культуре. Санкт-Петербург: Книгоиздательство «Образование».

9. Юм, Д. 1966. О партиях вообще. Москва: Мысль.

10. Šima, J. 2002. Za granice socialisma. Praha: Liberální institut.

\section{Інформація про автора}

Куц Галина Михайлівна - доктор політичних наук, професор, професор кафедри політології, соціології і культурології Харківського національного педагогічного університету імені Г.С. Сковороди; e-mail: galyna.kuts@i.ua; ORCID: http://orcid.org/00000002-7263-1958.

Стаття надійшла до редакції: 12.01.2019 р. Прийнята до друку: 24.01.2019 p 